
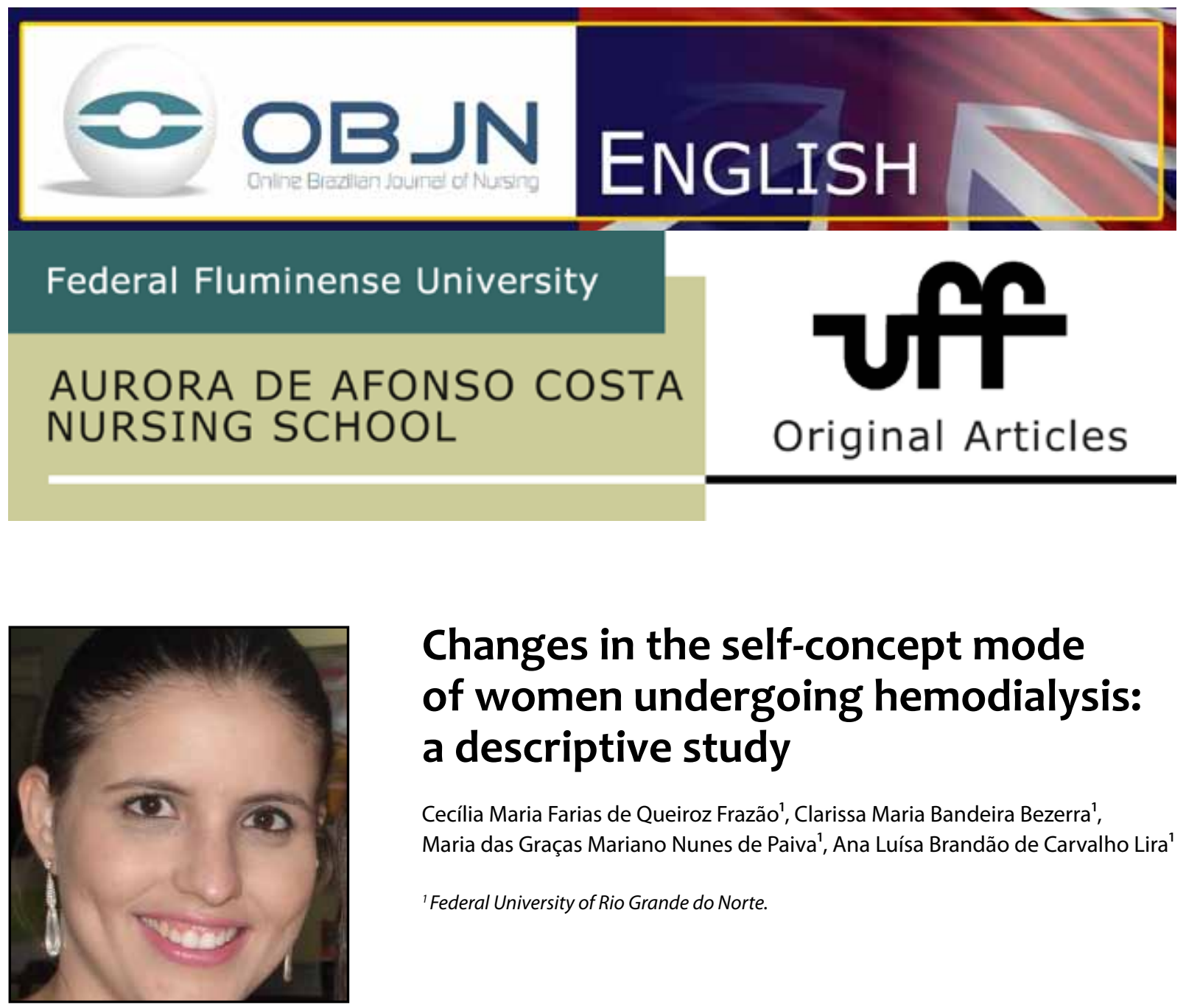

\title{
Changes in the self-concept mode of women undergoing hemodialysis: a descriptive study
}

Cecília Maria Farias de Queiroz Frazão', Clarissa Maria Bandeira Bezerra', Maria das Graças Mariano Nunes de Paiva', Ana Luísa Brandão de Carvalho Lira

${ }^{1}$ Federal University of Rio Grande do Norte.

\begin{abstract}
Aim: Identify the changes in the self-concept mode of Roy's theoretical model in women undergoing hemodialysis. Method: This is a descriptive study, carried out in a city in northeastern Brazil, which involved 24 women undergoing dialysis treatment due to chronic kidney disease (CKD). Results: The main alterations were: low self-esteem in the personal self and sexual dysfunction in the physical self, in terms of the self-concept mode. Discussion: Women undergoing hemodialysis present self-adaptive problems as in Roy's theoretical model; therefore, nurses should direct their care, emphasizing these adaptive problems. Conclusion: The changes identified in women undergoing hemodialysis were low self-esteem and sexual dysfunction, in terms of the self-concept mode of Roy's theoretical model.

Descriptors: Theory Nursing; Renal Dialysis; Renal Insufficiency, Chronic.
\end{abstract}




\section{INTRODUCTION}

According to the Brazilian Society of Nephrology, there are a growing number of people suffering from chronic kidney disease (CKD), who are subjected to dialysis treatment. In 2010, there were 49,077 patients undergoing hemodialysis treatment in Brazil, and of these patients, 21,103 were women. In 2011 there were 50,128 users, including 21,389 women $^{(1)}$.

Thus, CKD is understood as a national public health problem; therefore, it is necessary to understand the complexity of this condition, in order to contribute to biopsychosocial wellbeing and improvement in the quality of life for patients.

CKD is characterized by a decreased glomerular filtration rate, associated with structural and functional damage to the kidney, for a period exceeding three months ${ }^{(2)}$.

In the terminal phase of this disease, the treatment consists of renal replacement therapy: hemodialysis, peritoneal dialysis and transplant. Hemodialysis stands out in numerical terms, since about $90 \%$ of patients in dialysis therapy undergo this procedure ${ }^{(1)}$.

Hemodialysis corresponds to the extraction of toxic nitrogenous substances in the blood and the removal of 1 to 4 liters of fluid for an average period of four hours, three times a week ${ }^{(3)}$.

In this regard, chronic renal patients undergoing dialysis treatment suffer changes in lifestyle, which cause physical, sexual, psychological, family and social limitations, possibly affecting their quality of life $\mathrm{e}^{(4)}$.

When experiencing the daily life of these patients, one realizes that CKD and the hemodialysis treatment cause sudden changes in their daily routine, and the dexterity used by these patients to adapt can contribute to the adherence to biopsychosocial welfare and treatment ${ }^{(5)}$.
Female patients undergoing hemodialysis treatment may have psychological disorders, such as depression, due to the influence of physiological hormonal fluctuations, as well as damage caused by CKD, which includes loss of family role, reduced finances, unemployment, loss of libido, changes in self-esteem, insecurity and fear ${ }^{(6)}$.

Therefore, nurses must identify the individual needs of each patient, providing care aimed at better treatment adherence. Thus, it becomes important that nurses perform clinical and scientific reasoning, adopting care that is systematic and grounded by nursing theories.

Thus, based on this assumption, and on the need to understand the adaptations that patients on hemodialysis experience, we adopted Sister Callista Roy's theoretical Adaptation Model for the present study. It considers the person as an adaptive holistic system, with issues or inefficient adaptive responses.

\section{METHOD}

A descriptive study was carried out in a city in northeastern Brazil, in the period from March to June 2012. Interview scripts were studied, based on Roy's Adaptation Model and applied to 178 chronic renal failure patients undergoing hemodialysis in a referral clinic in the city, between October 2011 and February 2012. The interview was conducted by a nurse, who is a specialist in nephrology and had previously worked in a dialysis service. This nurse did not possess any type of relationship with the interviewees. Before starting the interview, the interviewer would outline the goals and rationale for conducting the research, and the fact that she was doing a master's in nursing.

To analyze the results, the selection of 24 interviews of female patients was performed, 
who showed changes in the self-concept mode of Roy's model, according to the clinical judgment of the authors after the reading of the statements contained in the interview script.

For the clinical judgment, we sought to identify the alterations in the thoughts of women undergoing hemodialysis and then classify them before the adaptive problems; focal, contextual and residual stimuli; and behaviors of the self-concept mode of Roy's theoretical model.

In the field, with the presentation of the statements, subjects were given code names of precious stones, preserving the confidentiality of their identities, and they were organized according to their adaptive problems: low selfesteem and/or sexual dysfunction, which are part of the changes in the self-concept mode of Roy's theoretical model.

The present study was approved by the Research Ethics Committee, Opinion No. 115/11-P CEP/UFRN.

\section{RESULTS}

The study participants included 24 patients, aged 24-60 years old, and their average age was 48.5 years old. Their educational level ranged from incomplete elementary education to complete higher education. The income of the women interviewed comes from a benefit provided by the government to those who are on hemodialysis. Most women (66.6\%) have a companion.

The 24 women in the study presented adaptive problems, namely: low self-esteem of the personal self and/or sexual dysfunction of the physical self, in terms of the self-concept mode of Roy's model. Of these, only 13 had sexual dysfunction, eight expressed low self- -esteem and three had both problems concomitantly.

For analysis of the changes in the self-concept mode of Roy's theoretical model in women undergoing hemodialysis therapy, some testimonials for each adaptive problem identified were selected.

Low self-esteem

“[...]I'm quiet, calm, anxious, but I feel very angry because I'm sick. I wanted things to go back to how they were, if I could go back in time[...]" (Amazonite)

"[...]l see myself as an old beaten finished woman... I wanted it to be like before. Health is everything in life. The disease catches up with the person so fast; we get older... I cry a lot when I see myself in this situation. I wish to enjoy my grandchildren more[...]" (Amber)

"I was so independent... Today I am a sad person for failing to do things... I changed a lot after the disease; I lost weight; I lost my left leg ... I'd rather be alone; people pity me... I have a sadness that will not leave me; I cry a lot[...]" (Aquamarine)

\section{Sexual dysfunction}

"[...]yes, I have sex with my husband, but it's not as good as before; I'm not happy... Then I don't want it anymore, I don't have any desire[...] (Tourmaline)

\footnotetext{
“[...] since I started hemodialysis, I have put on a lot of weight. I was very thin, really skinny. Look at me now... I still have sex, but I don't like it. My desire
} 
is gone, you know? I no longer have any desire[...] (Diamond)

“[...]Look, I'm full of stains throughout my body. I look in the mirror and I get terrified... I don't have sex as often as before; because I get very tired after... I don't have that excitement[...] (Quartz)

"[...]After the kidney problem, I got smaller and also lost my teeth... When I have sex with my husband I get short of breath, choking... I get stressed, I feel really stressed because I enjoyed it before, but now I have no interest; I don't want it anymore, but then there is my husband and he wants it[...]" (Agate)

Low self-esteem and sexual dysfunction

“[...] Nowadays, I feel different. I don't feel well. I am always indisposed. I have no desire to do anything. Do you know what I would like? I would like to go back to being what I was, to be willing, without pain, without any disease. Since I discovered the disease I prefer to be alone, I cannot eat, I spend a lot of time crying... It makes me angry, sad, fearful... I'm afraid to die... After the disease I had a physical defect in my back, in my bones, but I would love to be in good health. My sex life is active, but I get shortness of breath when I have relationships, so I have been avoiding it [...]" (Sapphire)

"[...] I see myself as a shy person... Closed... I don't really like to talk to people; it bothers me a lot. I wish to stop being this way. I cry a lot and I don't like anyone around me when I'm like that. The disease makes me very insecure, anxious and sometimes I get really angry for being in this situation... I gained a lot of weight after the illness, I'm very swollen and the scar from the fistula is very ugly. I have sex, but not as often because I don't feel good, especially when I'm swollen; I think I'm ugly, and sometimes my blood pressure drops[...] (Ruby)

"[...] I am a person who knows what to
do, I think. A positive, helpful, genuine person, but I wish I had studied more, had graduated. This disease made me very scared, insecure, and I get very anxious when I am stressed. I cry a lot... I don't like my arms because of the fistula scar. I don't like the restrictions that the disease causes me, because it takes me away from my friends. I have frequent sexual activity, but I don't do it on days when I am having hemodialysis because I get fatigued[...]" (Emerald)

When we verify the statements in the interview scripts, we note the behaviors related to the personal self, namely: the verbalization of negative feelings about the body; preoccupation with bodily changes; thoughts about feelings of shame, feelings of sadness, fear, anxiety and insecurity and; the verbalization of loss of libido. These behaviors are present to a greater or lesser extent, depending on the level of change which has occurred and the personal enhancement of each individual.

In this context, the statements reveal low self-esteem and sexual dysfunction as adaptive problems, by the presence of feelings of anxie- 
ty, isolation, helplessness and devaluation of corporal and social image.

In correlation, the factors contributing to low self-esteem and sexual dysfunction were lifestyle changes, caused by the limitations imposed by the treatment of CKD.

Thus, the adaptive problem of low self-esteem had as a focal stimulus, the chronic kidney disease; contextual stimuli were represented by physical and emotional exhaustion; residual stimuli were represented by feelings of worthlessness and; as behavior, self-destructive reports.

Sexual dysfunction was also associated with the focal stimulus, the chronic kidney disease; the contextual stimuli were represented by loss of libido; and behaviors including decrease in frequency and in the interest of intercourse. There was no residual stimulus.

\section{DISCUSSION}

In Sister Callista Roy's Adaptation Model, one realizes the existence of a link between nursing, the person, health and the environment. It is also evident that the person seeks, in the environment, stimuli capable of triggering a response from an adaptive mechanism. This model consists of four adaptive modes that control the process. They are: the physical-physiological mode, self-concept, the role performance mode and the interdependence mode ${ }^{(7)}$.

The self-concept mode is defined by a set of beliefs and feelings that a person develops for himself at a certain time, which governs his own conduct. It comprises the physical self, which are the feelings that a person has of his own body image and personal self, characterized by its own consistency through the ideals, expectations and moral-ethics-spirituality ${ }^{(7)}$.

The adaptive problems identified in the physical self are: body image disturbance; sexual dysfunction; rape trauma syndrome; loss; ineffective interpersonal relationships; oppressive culture; low morale and stigma. The adaptive problems in the personal self are: anxiety; helplessness; guilt; low self-esteem; abusive relations and worthless relationships ${ }^{(7)}$. In the present study, we emphasize that the adaptive low self-esteem problems and sexual dysfunction were traced.

Low self-esteem corresponds to the individual's own estimates, their self-evaluation, expectations and values, the desire to be different and their feelings and beliefs ${ }^{(8)}$. In this context, the expressed sentiments that prevailed in the present study in terms of low self-esteem were: sadness and fear.

Hemodialysis patients have feelings of sadness, weakness and uncertainty. Sadness is related to chronic disease, the dialysis treatment and the drastic changes in their lives, such as feeling fatigued and unable to participate in family and social gatherings. Furthermore, they expressed feelings of uncertainty and fear associated with life, death, dialysis and the future ${ }^{(9)}$.

Research shows that CKD and its treatment affect the daily lives of patients, since they generate limitations caused by physical health problems and limitations caused by emotional health problems ${ }^{(10-12)}$. Modifications are also made to the body, caused by the arteriovenous fistula (AVF) and catheters, as well as changes in the performance of daily activities, imposed by the physical limitation of an upper limb due to the $\operatorname{AVF}^{(4)}$.

Another aggravating factor of low self-esteem is the decrease in the economic and professional activities of these patients, since they cannot keep on working, probably due to the prolonged duration of hemodialysis and to complaints of physical weakness, fatigue and malaise $^{(4,9-12)}$. 
Sexual dysfunction, which is defined by unsatisfactory, unrewarding and/or inadequate changes in any phase of the sexual function, is directly related to the appearance, function, sexuality and the health and disease condition $^{(7)}$.

In this respect, the manifestations displayed by these patients were mostly about body image, the changes caused to it, loss of libido and, consequently, the reduction of sexual activity.

A study that evaluated the quality of life and sexual dysfunction in patients on dialysis, due to chronic renal failure, indicates that the sexual problems of these patients can be justified by the presence of organic and emotional distress, as well as the condition that the patient is submitted to ${ }^{(11)}$.

Men on dialysis treatment refer to strategies that deal with the limitations of sexuality, such as drug therapy, group therapy and advice given by health professionals, for having a healthier sex life ${ }^{(13)}$.

A study found that sexual problems, such as reduced libido, affect women on dialysis treatment for CKD more than men and that a possible reason for this problem is the psychological factor ${ }^{(14)}$.

Furthermore, renal patients on hemodialysis suggest that the support of family and the hemodialysis staff is essential to facilitate coping in this moment of their lives ${ }^{(15)}$.

Thus, the identification of nursing problems in the population suffering from renal disease is of paramount importance, in order to facilitate effective practices, since it provides a different perspective, aiding in the decision-making process in terms of better care situations $^{(16)}$.

Given the above, a care service that encompasses the patient, family members and professionals in search of education and awa- reness interventions, aimed at the adaptation and balance of patients, is necessary.

\section{CONCLUSION}

The main changes in the self-concept mode of Roy's theoretical model, in women suffering from chronic kidney disease and undergoing hemodialysis, were related to adaptive problems: low self-esteem and sexual dysfunction.

As for the personal self in the self-concept mode, low self-esteem and feelings of sadness and fear were expressed. Furthermore, in relation to the physical self in the self-concept mode, there is an intolerance concerning body image, the changes caused in the body in terms of discomfort felt by the appearance of the fistula, loss of libido and reduced sexual activity.

Thus, from the data found, and compared with the literature, a nursing care plan focused on these patients, with emphasis on the major adaptive problems of the self-concept mode of Roy's theoretical model, becomes possible. We know, therefore, that the nurse's role is to propose individualized care and quality, always focusing on the main problems encountered by these patients.

As a limitation of the study, we highlight the fact that the approach was performed only in the self-concept mode of Roy's theoretical model; therefore, we encourage the approach of new studies to include other modes.

\section{REFERENCES}

1. Sesso RCC, Lopes AA, Thomé FS, Lugon JR, Burdmann EA. Brazilian Dialysis Census, 2009. J Bras Nefol [serial in the internet]. 2010 [cited 2013 Jan 20]; 32(4):380-4. Available from: http://www. scielo.br/pdf/jbn/v32n4/en_v32n4a07.pdf. 
2. Bastos MG, Bregman R, Kirsztajn GM. Doença renal crônica: frequente e grave, mas também prevenível e tratável. Rev Assoc Med Bras [serial in the internet]. 2010 [cited 2013 Jan 25]; 56(2):248-53. Available from: http://www.scielo. br/pdf/ramb/v56n2/a28v56n2.pdf.

3. Matos EF, Lopes A. Modalidades de hemodiálise ambulatorial: breve revisão. Acta paul. enferm. [serial in the internet]. 2009 [cited 2013 Jan 7]; 22:569-71. Available from: http://www.scielo.br/ pdf/ape/v22nspe1/25.pdf.

4. Silva AS, Silveira RS, Fernandes GFM, Lunardi VL, Backes VMS. Percepções e mudanças na qualidade de vida de pacientes submetidos à hemodiálise. Rev Bras Enferm [serial in the internet]. 2011 [cited 2013 Jan 12]; 64(5):839-44. Available from: http://www.scielo.br/pdf/reben/ v64n5/a06v64n5.pdf.

5. Barbosa GS, Valadares GV. Hemodialysis: patientís adaptation and life style. Acta paul. enferm. [serial in the internet]. 2009 [cited 2013 Jan 24]; 22:524-7. Available from: http://www.scielo.br/ pdf/ape/v22nspe1/en_14.pdf.

6. Nifa S, Rudnicki T, Canoas U. Depressão em pacientes renais crônicos em tratamento de hemodiálise. Rev. SBPH. [serial in the internet]. 2010 [cited 2013 Jan 21]; 13(1)64-75. Available from: http://pepsic.bvsalud.org/pdf/rsbph/ v13n1/v13n1a06.pdf

7. Roy C, Andrews HA. The Roy Adaptation Model. 3rd ed. Upper Saddle River, New Jersey: Pearson; 2009.

8. Bertolin DC, Pace AE, Kusumota L, Haas V. An association between forms of coping and the socio-demographic variables of people on chronic hemodialysis. Rev Esc Enferm USP [serial in the internet]. 2011 [cited 2013 Jan 15]; 45(5):1070-6. Available from: http://www.scielo. br/pdf/reeusp/v45n5/en_v45n5a06.pdf.

9. Wadd K, King L, Bennett P, Grant J. Being a parent on dialysis: a literature review. J Ren Care [serial in the internet]. 2011 [cited 2013 Jan 28]; 37(4):208-15. Available from: http:// onlinelibrary.wiley.com/doi/10.1111/j.17556686.2011.00220.x/pdf.

10. Santos I, Rocha RPF, Berardinelli LMM. Qualidade de vida de clientes em hemodiálise e necessidades de orientação de enfermagem para o autocuidado. Esc. Anna Nery Rev. Enferm. [serial in the internet]. 2011 [cited 2013 Jan 10]; 15(1):31-8. Available from: http://www.scielo. br/scielo.php?script=sci_arttext $\&$ pid=S1414$-81452011000100005 \&$ Ing=en\&nrm=iso.

11. Nóra RT, Zambone GS, Facio Júnior FN. Avaliação da qualidade de vida e disfunções sexuais em pacientes com insuficiência renal crônica em tratamento dialítico em hospital. Arq. ciênc. saúde. [serial in the internet]. 2009 [cited 2013 Jan 12];16(2):72-5. Available from: http://www. cienciasdasaude.famerp.br/racs_ol/vol-16-2/ ID357.pdf.

12. Mantovani M, Mendes F. The quality of life of elderly's chronic disease sufferers: qualitative-quantitative research. Online braz. j. nurs. [serial in the Internet]. 2010; [Cited 2013 Jan 22]; 9(1):12. Available from: http://www.objnursing.uff.br/ index.php/nursing/article/view/2835.

13. Fonseca RD, Schwartz E, Santana MG, Vestena ZJG, Costa VA, Pozza SB et al. Vivências dos homens submetidos à hemodiálise acerca de sua sexualidade. Av. enferm. [serial in the Internet]. 2011 [cited 2013 Jan 10];29(2): 255262. Available from: http://www.scielo.org. co/scielo.php?script=sci_arttext\&pid=S0121$-45002011000200005 \&$ Ing $=$ en.

14. Muñoz-García VE, Vaca-Ruíz AM, Romero-Estudillo E, García-Criado J, Bagdad-Abselam A, Mohamed-Maanan Nayet. Comportamiento sexual en los pacientes de hemodiálisis en Melilla. Rev. Soc. Esp. Enferm. Nefrol. [serial in the internet]. 2010 [cited 2012 Jan 8]; 13(2):113-8. Available from: http://www.revistaseden.org/ files/2388_comportamiento.pdf

15. Grasselli CSM, Chaves ECL, Simão TP, Botelho PB, Silva RR. Avaliação da qualidade de vida dos pacientes submetidos à hemodiálise. Rev Bras Clin Med. [serial in the internet]. 2012; [cited 2014 Apr 24]; 10(6): 503-7. Available from: http://files.bvs.br/upload/S/1679-1010/2012/ v10n6/a3185.pdf

16. Souza GR, Avelar MCQ. Nursing Diagnosis in care of patients with Renal Insufficiency Acute: Delphi Technique. Online braz. j. nurs. (Online). [serial In the Internet]. 2009; [cited 2013 Jan 5]; 8(1):1-2. Available from: http://www.objnursing. uff.br/index.php/nursing/article/view/2059. 
* Study funded by the universal edict of the National Received: 02/18/2013 Council for Scientific and Technological Development (Process No. 483285/2010-2).

Revised: 04/28/2014

Approved: 04/14/2014

All authors participated in the phases of this publication in one or more of the following steps, in According to the recommendations of the International Committee of Medical Journal Editors (ICMJE, 2013): (a) substantial involvement in the planning or preparation of the manuscript or in the collection, analysis or interpretation of data; (b) preparation of the manuscript or conducting critical revision of intellectual content; (c) approval of the versión submitted of this manuscript. All authors declare for the appropriate purposes that the responsibilities related to all aspects of the manuscript submitted to OBJN are yours. They ensure that issues related to the accuracy or integrity of any part of the article were properly investigated and resolved. Therefore, they exempt the OBJN of any participation whatsoever in any imbroglios concerning the content under consideration. All authors declare that they have no conflict of interest of financial or personal nature concerning this manuscript which may influence the writing and/or interpretation of the findings. This statement has been digitally signed by all authors as recommended by the ICMJE, whose model is available in http://www.objnursing.uff.br/normas/DUDE_eng_1306-2013.pdf 